DOI 10.31558/2307-2318.2020.3.10
УДК 339.96
JEL: F15, L26

Воронін А.B.,

кандидат економічних наук,

доцент кафедри підприємництва, корпоративної та просторової економіки,

Донецький національний університет імені Василя Стуса

ORCID: 0000-0002-8788-9644

a.voronin@donnu.edu.ua

Орел Л.В.,

Донецький національний університет імені Василя Стуса

ORCID ID: 0000-0002-5261-5504

orel.l@donnu.edu.ua

\title{
РОЗРОБКА СТРАТЕГІЇ ПІДВИЩЕННЯ КОНКУРЕНТОСПРОМОЖНОСТІ ПРОДУКЦІЇ ПРОМИСЛОВОГО ПІДПРИЕМСТВА ПАТ «ЖИТОМИРСЬКИЙ МАСЛОЗАВОД»
}

У статті досліджено сутність та складові конкурентоспроможності продукції, розглянуто поняття «конкурентоспроможність» 3 погляду різних видатних науковців, досліджені проблеми в формуванні ефективної конкурентної стратегії організаці та визначено фактори, котрі слід враховувати при формуванні конкурентної стратегії організації, обгрунтовані підходи до визначення механізму формування стратегії підвищення конкурентоспроможності продукції, розглянуті ключові етапи здійснення конкурентної стратегії організації. Встановлено, що конкурентні стратегії мають свої характерні особливості і повинні застосовуватися зважено і продумано. Також наведено рейтинг ТОП-5 лідерів ринку морозива в Україні та представлена порівняльна характеристика ключових конкурентів ПАТ «Житомирський маслозавод», котрі діють на конкурентному ринку. Визначено заходи підвищення конкурентоспроможності продукції ПАТ «Житомирський маслозавод» та його перспективні конкурентні стратегії за матрицею Мак-Кінзі та матрицею Хофера-Шенделя.

Ключові слова: конкурентоспроможність, продукція, стратегія, управління, формування.

Рис. -2 , Табл. -1 , Літ. -6

Воронин А.B.,

кандидат экономических наук,

доцент кафедры предпринимательства, корпоративной и пространственной экономики,

Донецкий национальный университет имени Васыля Стуса

ORCID: 0000-0002-8788-9644

a.voronin@donnu.edu.ua

Орел Л.В.,

Донецкий национальный университет имени Васыля Стуса

ORCID ID: 0000-0002-5261-5504

orel.l@donnu.edu.ua 


\title{
РАЗРАБОТКА СТРАТЕГИИ ПОВЫШЕНИЯ КОНКУРЕНТОСПОСОБНОСТИ ПРОДУКЦИИ ПРОМЫШЛЕННОГО ПРЕДПРИЯТИЯ ПАО «ЖИТОМИРСКИЙ МАСЛОЗАВОД»
}

В статье исследована сущность и составляющие конкурентоспособности рассмотрено понятие «конкурентоспособность» $c$ точки зрения различных выдающихся ученых, исследованы проблемь в формировании эффективной конкурентной стратегии организачии и определены факторы, которые следует учитывать при формировании конкурентной стратегии организации, обоснованные подходы $\kappa$ определению механизма формирования стратегии повышения конкурентоспособности продукиии, рассмотрены ключевые этапы осуществления конкурентной стратегии организачии. Установлено, что конкурентные стратегии имеют свои характерные особенности и должны применяться взвешенно и продуманно. Также приведены рейтинг ТОП-5 лидеров рынка мороженого в Украине и представлена сравнительная характеристика ключевых конкурентов ПАО «Житомирский маслозавод», которые действуют на конкурентном рынке. Определены меры повышения конкурентоспособности продукции ПАО «Житомирский маслозавод»и перспективные конкурентные стратегии ПАО «Житомирский маслозавод» по матрице Мак-Кинзи и матрицей Хофера-Шенделя.

Ключевые слова: конкурентоспособность, продукция, стратегия, управление, формирование.

Рис. -2 , Табл. -1 , Лит. -6

\author{
A. Voronin, \\ PhD, Associate Professor, \\ Department of Entrepreneurship, Corporate and Spatial Economics, \\ Vasyl Stus Donetsk National University \\ ORCID: 0000-0002-8788-9644 \\ a.voronin@donnu.edu.ua \\ L. Orel, \\ Vasyl Stus Donetsk National University \\ ORCID ID: 0000-0002-5261-5504 \\ orel.l@donnu.edu.ua

\section{DEVELOPMENT OF A STRATEGY FOR INCREASING THE COMPETITIVENESS OF PRODUCTS OF THE INDUSTRIAL ENTERPRISE OF PJSC «ZHYTOMYR BUTTER PLANT»}

The article examines the essence and components of product competitiveness, considers the concept of "competitiveness" from the point of view of various prominent scientists, explores the problems in forming an effective competitive strategy of the organization and identifies factors to consider in forming a competitive strategy, the approaches to definition of the mechanism of formation of strategy of increase of competitiveness of production are substantiated, the key stages of realization of competitive strategy of the organization are considered. 
It is established that competitive strategies have their own characteristics and should be applied carefully and thoughtfully. The rating of TOP-5 leaders of the ice cream market in Ukraine is also given and the comparative characteristics of the key competitors of PJSC "Zhytomyr Butter Plant" operating in the competitive market are presented. Measures to increase the competitiveness of PJSC "Zhytomyr Butter Plant" and promising competitive strategies of PJSC "Zhytomyr Butter Plant" based on the McKinsey matrix and the Hofer-Shendel matrix are identified.

Keywords: competitiveness, products, strategy, management, formation/

Fig. -2 , Tab. -1 , Ref. -6

Постановка проблеми. Проблеми в формуванні ефективної конкурентної стратегії організацій пов'язані, перш за все, 3 динамічністю розвитку вітчизняного ринку в умовах глобалізації світової економіки, наявністю багатьох форм світової конкуренції в різноманітних галузях, значною часткою монопольного сектору в українській економіці, недостатнім досвідом роботи вітчизняних компаній. Актуальність теми обумовлена тим, що неабиякий вплив на сучасну ситуацію в ринковому просторі здійснюють кризові явища, наслідки котрих помітні в компаніях всіх сфер діяльності, в тому числі й харчової промисловості. За даних умов значно підвищується роль стратегії, вона дає змогу сформувати пріоритетні напрямки розвитку компанії.

Аналіз останніх досліджень і публікацій. Теоретичну основу дослідження питань вивчення та розробки ефективної стратегії підвищення конкурентоздатності продукції склали наукові праці зарубіжних та вітчизняних вчених, таких як: Губанов В.А., Бурачек I.В.., Старостіна А.О., М. Портер, Должанський І.З., Лахтіонова Л. А., Носова С. С., Шеремет А. Д., Юданов А. Ю. та інших.

Виділення не вирішених раніше частин загальної проблеми. Для того, щоб розроблена стратегія була ефективною, слід докласти неабияких зусиль по вдосконаленню самого процесу іiі формування. У зв'язку с цим постають питання вдосконалення методики розробки стратегії підвищення конкурентоспроможності продукції промислового підприємства.

Мета статті. Головною метою цієї роботи є дослідження теоретичних засад розробки стратегії підвищення конкурентоспроможності продукції промислового підприємства.

Виклад основного матеріалу. Проблемі конкурентоздатності продукції приділяється значна увага як з боку зарубіжних, так і зі сторони вітчизняних учених, проте загальновживаного трактування суті даної економічної категорії ще й досі не існує. Вважається, що конкурентоспроможність виробу - це комплекс його властивостей задовольняти вимоги ринку у певний момент, яка характеризується споживчими характеристиками, сподобаннями споживача та кон'юнктурою ринку відповідних продуктів. Прийнятої розрізняти такі різновиди конкурентоспроможності: продукції, організації, галузі, економіки країни.

М.Портер дане поняття трактує так: «конкурентоспроможність - це охарактеризоване сукупністю чинників положення організації на внутрішніх та зовнішніх ринках, котре відображається в певній сукупності показників» [4, с.24].

В роботі Должанського I.3. [2, с.104] зазначається, що під конкурентоздатністю

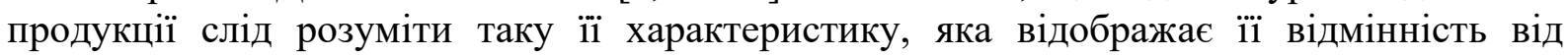
продукції конкурента як за ступенем відповідності конкретній суспільній потребі, так і за витратами на іiі задоволення. Показник, що відображає таку відмінність, показує ступінь конкурентоздатності продукції, що аналізується, в порівнянні $з$ продукцією- 
конкурентом. Отже, для аналізу конкурентоспроможності продукції варто зіставляти параметри виробу, що аналізується, і продукцію-конкурента 3 рівнем, який задається потребами покупця, а потім порівнювати одержані показники.

I.B. Бурачек наголошує, що конкурентоспроможність продукції -здатність організації відшукувати, виготовляти і продавати продукцію та надавати послуги, ціна та нецінові характеристики котрих більш привабливі, ніж в головних конкурентів, котрі виготовляють аналогічну продукцію[1, с.289].

В сьогоднішніх реаліях ринкової економіки оцінка конкурентоздатності продукції організації являється об'єктивною потребою, так я в сучасній конкурентній боротьбі переможе той, хто активно буде відстоювати і проводитиме власну політику в області конкурентоздатності продукції.

Формування ефективної стратегії конкуренції організації згідно з ринковими позиціями пов'язано з виокремленням їі переваг та ризиків, оцінкою іiі відповідності ситуації на ринку та ступеня організації виробництва в компанії та керування ним.

На формування конкурентної стратегії організації впливає багато факторів, котрі слід враховувати: конкурентна ситуацію на певному ринку; види конкурентів; фаза ЖЦТ; можливості щодо виробництва товарів; забезпечення ії якісних характеристик тощо.

Потрібно зазначити, що алгоритм формування ефективної стратегії конкуренції в компанії має бути комплексним та завершеним. На рис.1. наведені ключові етапи формування конкурентної стратегії, а в табл. 1 представлена характеристика кожного з зазначених етапів.

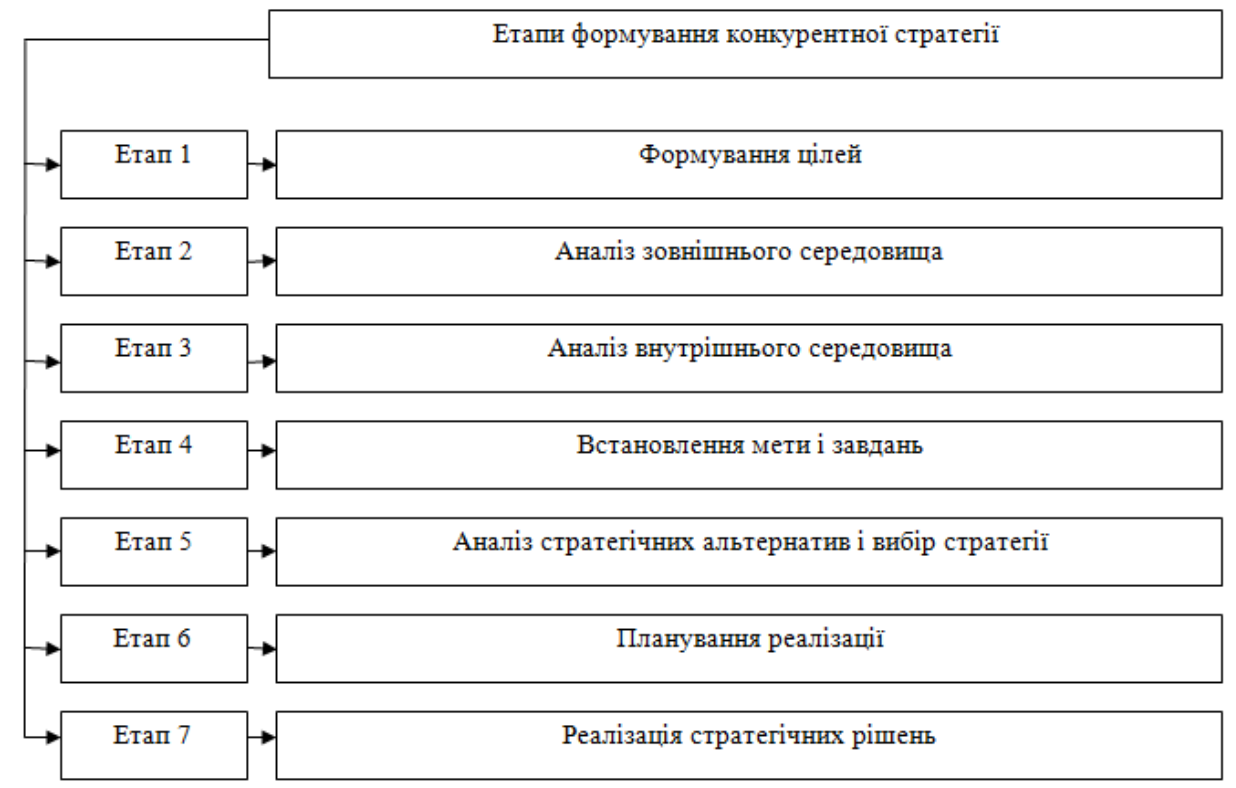

\section{Рисунок 1 - Алгоритм формування і реалізації стратегії конкуренції організації}

Стратегія компанії формально знаходить власне відображення в документі, котрий називається стратегічним планом.

Не можна не відмітити складність обрання дієвої конкурентної стратегії з усього переліку стратегій за умов неодмінного врахування всіх важливих чинників. Тому важливим кроком аналізу має стати розробка алгоритму ефективного обрання конкурентної стратегії, що враховує більшість ринкових чинників впливу, дозволяє проводити критичний кількісний та якісний аналіз стратегічних альтернатив та має на 
меті застосування оптимального комплексу інструментів. Це дасть змогу розробити конкурентну стратегію компанії та забезпечити її ефективну реалізацію.

Ринкові умови ведення бізнесу потребують підтримки високого ступеня конкурентоздатності - однієї із ключових складових успіху компанії як на внутрішніх, так і зарубіжних ринках. Саме керування процесами конкурентоздатності допоможе організації постійно вдосконалюватися та управляти всіма процесами в компанії, які дають змогу досягнути конкурентних переваг з подальшими наслідками, що в кінцевому результаті призведуть до прибуткової діяльності підприємства.

АТ «Житомирський маслозавод» — компанія «Рудь» — лідер серед українських виробників морозива. Застосування новітніх технологій та підходів до роботи, міцні партнерські зв'язки, вірність традиціям дозволяє завжди та в усьому бути на крок попереду — підприємство працює для споживачів[6].

За даними аналітичної компанії AR-group, в рейтингу TOП-5 лідерів ринку морозива в Україні склад компаній розташувався: ПАТ «Житомирський маслозавод» (ТМ Рудь) 26,7\%, «Ласунка» (ТМ Ласунка) - 23,8\%, «Львівський холодокомбінат» (ТМ Лімо) 15,6\%, «Фірма Ласка» (ТМ Ласка) - 13,9\% і «Хладопром» (ТМ Хладік) - 9,9\% [5].

Таблиця 1

Ключові етапи формування та здійснення конкурентної стратегії організації

\begin{tabular}{|c|c|}
\hline Етап & Характеристика \\
\hline $\begin{array}{l}\text { Встановлення } \\
\text { цілей }\end{array}$ & $\begin{array}{l}\text { Формування та трактування коротко-, середньо- і довгострокових завдань компанії потребує } \\
\text { ефективного підходу, так як це плацдарм для обрання конкурентної стратегії. }\end{array}$ \\
\hline $\begin{array}{l}\text { Оцінка } \\
\text { зовнішнього } \\
\text { оточення }\end{array}$ & $\begin{array}{l}\text { Алгоритм оцінки організаційного середовища компанії, що ідентифікується } 3 \text { поточними і } \\
\text { майбутніми погрозами та сприятливими можливостями, котрі можуть здійснювати вплив на } \\
\text { досягнення ключових цілей }\end{array}$ \\
\hline $\begin{array}{c}\text { Оцінка } \\
\text { внутрішнього } \\
\text { оточення }\end{array}$ & $\begin{array}{l}\text { Означення внутрішніх змін компанії, котрі можуть розглядатися як його сильні сторони, аналіз } \\
\text { їх важливості та можливості стати базою конкурентних переваг. Оцінка складається } 3 \\
\text { дослідження двох областей компанії: макросередовища (порівняння ресурсів компанії й й } \\
\text { ефективності їх використання } 3 \text { іншими організаціями галузі (регіону) для обрання } \\
\text { оптимального конкурентного розвитку); мікросередовища (досліджується внутрішнє } \\
\text { середовище тільки по конкретній стратегічній зоні господарювання (СЗГ): дослідження ресурсів } \\
\text { підприємства в даній СЗГ; оцінка ефективності виробничо-збутової діяльності організації). }\end{array}$ \\
\hline $\begin{array}{l}\text { Формування мети і } \\
\text { завдань }\end{array}$ & $\begin{array}{l}\text { Характеристика за допомогою комплексного аналізу зовнішнього і внутрішнього оточення, } \\
\text { рамок в діяльності компанії, загроз і можливостей, перспектив розвитку. Здійснення } \\
\text { сформованої стратегії потребує розробки комплексу стратегічних альтернатив, котрі } \\
\text { враховують специфіку цільового ринку. }\end{array}$ \\
\hline $\begin{array}{c}\text { Аналіз } \\
\text { стратегічних } \\
\text { альтернатив і } \\
\text { вибір стратегії }\end{array}$ & $\begin{array}{l}\text { Види критеріїв обрання альтернатив: реакція на можливості / загрози зовнішнього оточення; } \\
\text { одержання конкурентних переваг; відповідність цілям компанії; реальність стратегії; } \\
\text { відповідність стратегічним, фінансовим завданням і обмеженням. }\end{array}$ \\
\hline План реалізації & $\begin{array}{l}\text { Складання детального плану впровадження в життя обраної стратегії з означенням строків } \\
\text { поетапної реалізації та очікуваних результатів. }\end{array}$ \\
\hline $\begin{array}{c}\text { Виконання } \\
\text { стратегічних } \\
\text { рішень }\end{array}$ & $\begin{array}{l}\text { Проводиться в таких межах: 1) застосування адміністративних чинників; 2) використання } \\
\text { економічних важелів, способом формування бюджету, використання системи показників та } \\
\text { управління за цілями. Необхідно, щоб всі розроблені рішення довелись до відома певних } \\
\text { виконавців під виглядом затверджених планів, наказів та інших розпорядчих документів. }\end{array}$ \\
\hline
\end{tabular}

Джерело: складено автором за [3]

Опишемо більш детально основних гравців на ринку продукції, котрі виробляють морозиво (табл. 2). 
Необхідно враховувати фактори, що впливають на поведінку покупців, на їх попит. Споживчий попит також являється вирішальним чинником у діяльності ПАТ «Житомирський маслозавод».

Економічний стан 3 початку 2020 року значно погіршився та характеризується негативними зрушеннями, зокрема дестабілізацією макроекономіки, значним зростанням інфляції, погіршенням інвестиційної діяльності. Обсяги споживання деяких не життєво необхідних продуктів (морозиво) напряму залежать від економічної стабільності в країні та рівня доходів населення, адже не є товарами першої необхідності. Отже, ці фактори є визначними у розвитку даної галузі.

Таблиця 2

Порівняльна характеристика конкурентів ПАТ «Житомирський маслозавод»

\begin{tabular}{|c|c|c|}
\hline $\begin{array}{c}\text { Торгова марка } \\
\text { (ТМ) }\end{array}$ & Характеристика & $\begin{array}{c}\text { Переваги / Недоліки в порівнянні } 3 \\
\text { ТМ Рудь }\end{array}$ \\
\hline ТМ Ласунка & $\begin{array}{l}\text { В компанії працюють понад } 1000 \text { людей, це } \\
\text { група 3 п'яти підприємств. Виробництва } \\
\text { знаходяться в містах: Дніпро, Тернопіль, } \\
\text { Нікополь. Виробляє понад 23,5 тис. тонн } \\
\text { морозива }\end{array}$ & $\begin{array}{l}\text { Міжнародний сертифікат } \mathrm{FSSC} \\
22000 . \text { До реклами залучають } \\
\text { відомих зірок, наприклад } \\
\text { Полякову. Більший асортимент ніж } \\
\text { у ТМ Рудь. }\end{array}$ \\
\hline ТМ Лімо & $\begin{array}{l}\text { Львівський холодокомбінат входить у п'ятірку } \\
\text { найкращих українських виробників морозива. В } \\
\text { асортименті підприємства } 110 \text { різновидів } \\
\text { морозива. }\end{array}$ & $\begin{array}{l}\text { За результатами конкурсу на } \\
\text { найкращий дизайн упаковки - } \\
\text { одразу три золоті медалі. Менші } \\
\text { потужності ніж у ТМ Рудь, гірша } \\
\text { рекламна компанія }\end{array}$ \\
\hline ТМ Ласка & $\begin{array}{l}\text { Сьогодні LASKA } є \text { одним } 3 \text { лідерів ринку } \\
\text { морозива. } 32000 \text { року продукція компанії } \\
\text { широко представлена у всіх регіонах країни, а } \\
\text { також активно реалізується за ï межами - } \\
\text { Молдова, Грузія, Азербайджан, Ізраїль, } \\
\text { Сенегал, Ірак та ін.. }\end{array}$ & $\begin{array}{l}\text { Міжнародний сертифікат FSSC } \\
\text { 22000. Менші потужності, менший } \\
\text { асортимент ніж у ТМ Рудь }\end{array}$ \\
\hline ТМ Хладік & $\begin{array}{l}\text { Потужності виробництва АТ «Хладопром» } \\
\text { дозволяють виробляти більше } 100 \text { тонн } \\
\text { морозива на добу. Асортимент становить більше } \\
80 \text { видів. }\end{array}$ & $\begin{array}{l}\text { Менші потужності, менший } \\
\text { асортимент ніж у ТМ Рудь. Гірша } \\
\text { рекламна компанія }\end{array}$ \\
\hline
\end{tabular}

Джерело: складено автором

До 2019 року зростали доходи населення, проте з березня 2020 року доходи почали різко скорочуватись через карантинні заходи по країні. За останні місяці відбулося зниження доходів домогосподарств на $30-35 \%$, а також кількості домогосподарств, які робили заощадження. Цей факт значною мірою впливає на купівельну спроможність громадян, а отже на кількість продаж ПАТ «Житомирський маслозавод».

Більш ефективною для підвищення конкурентоспроможності продукції ПАТ «Житомирський маслозавод» $\epsilon$ застосування стратегії розвитку продукції, яка передбачає інвестування в ресурси організації 3 метою вдосконалення якості випускаємої продукції.

Для обрання стратегії ПАТ «Житомирський маслозавод» в залежності від конкурентної позиції та привабливості галузі можна використати матрицю Мак-Кінзі (рис. 2).

Отже, для ПАТ «Житомирський маслозавод» ефективною $\epsilon$ стратегія інвестування, а саме - інвестування в розвиток та оновлення асортименту, які затребувані споживачами. Позиції підприємства на ринку сильні, проте існує ризик їх послаблення через ігнорування вкладу інвестицій в розвиток компанії. 


\begin{tabular}{|c|c|c|c|c|}
\hline & $\begin{array}{c}\text { Перспективна стратегія } \\
\text { для ПАТ «Житомирський } \\
\text { маслозавод» }\end{array}$ & & \\
\hline & & \multicolumn{3}{|c|}{ Конкурентні позиції } \\
\hline & & Сильні & Середні & Слабкі \\
\hline \multirow{3}{*}{ 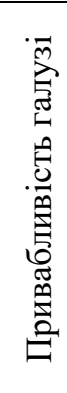 } & Сильна & $\begin{array}{c}\text { Утримання позицій/ } \\
\text { інвестування }\end{array}$ & $\begin{array}{c}\text { Інвестування/ } \\
\text { реінвестування } \\
\text { прибутку }\end{array}$ & $\begin{array}{c}\text { Інвестування/ } \\
\text { реінвестування/ } \\
\text { вихід з ринку }\end{array}$ \\
\hline & Середня & $\begin{array}{c}\text { Реінвестування } \\
\text { прибутку/ } \\
\text { Максимізація вигоди }\end{array}$ & $\begin{array}{c}\text { Максимізація } \\
\text { вигоди/ вихід } 3 \\
\text { ринку }\end{array}$ & $\begin{array}{c}\text { Залишитись/ } \\
\text { Повільний вихід }\end{array}$ \\
\hline & Слабка & $\begin{array}{c}\text { Максимізація вигоди/ } \\
\text { вихід з ринку }\end{array}$ & Повільний вихід & $\begin{array}{c}\text { Швидкий або } \\
\text { повільний вихід/ } \\
\text { залишитись }\end{array}$ \\
\hline
\end{tabular}

\section{Рисунок 2 - Перспективні конкурентні стратегії ПАТ «Житомирський маслозавод» за матрицею Мак-Кінзі}

Здійснимо вибір стратегії ПАТ «Житомирський маслозавод» 3 застосуванням матриці Хофера Шенделя, котра наведена (рис. 3).

\begin{tabular}{|c|c|c|c|c|c|}
\hline & \multicolumn{4}{|c|}{ Конкурентні позиції } \\
\hline & & Сильні & Середні & Слабкі & Найгірші \\
\hline \multirow{5}{*}{ 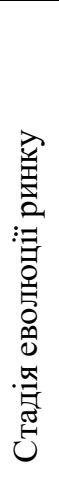 } & $\begin{array}{l}\text { Розвиток / } \\
\text { витіснення }\end{array}$ & \multicolumn{3}{|c|}{ Стратегії збільшення ринкової частки } & \multirow{6}{*}{$\begin{array}{c}\text { Розкручення } \\
\text { або } \\
\text { ліквідація } \\
\text { або } \\
\text { відмова }\end{array}$} \\
\hline & Зростання & \multirow{2}{*}{\multicolumn{3}{|c|}{$\begin{array}{c}\text { Стратегії зростання (для ПАТ «Житомирський маслозавод» зважаючи на те, } \\
\text { що воно знаходиться на стадії зростання ринку вперспективними саме } \\
\text { стратегії зростання. В даному випадку ефективними є стратегії зростання } \\
\text { доходів шляхом введення в асортимент нових, більш затребуваних та } \\
\text { прибуткових товарних груп. }\end{array}$}} & \\
\hline & \multirow{2}{*}{$\begin{array}{c}\text { Зрілість/ } \\
\text { насичення }\end{array}$} & & & & \\
\hline & & Стратегії & я прибутку & \multirow[t]{2}{*}{$\begin{array}{c}\text { Концентрація на } \\
\text { своєму ринку }\end{array}$} & \\
\hline & Скорочення & \multirow{2}{*}{\multicolumn{2}{|c|}{ Стратегії скорочення активів }} & & \\
\hline & & & & & \\
\hline
\end{tabular}

\section{Рисунок 3 - Перспективна стратегія для ПАТ «Житомирський маслозавод» згідно матриці Хофера-Шенделя}

Зважаючи на те, що ПАТ «Житомирський маслозавод» знаходиться на стадії зростання ринку та має конкурентну сильну позицію підприємства на ринку, визначено перспективними саме стратегії зростання. В даному випадку ефективними $є$ стратегії зростання доходів шляхом нарощення обсягів збуту. 
Вибір стратегії удосконалення конкурентоспроможності продукції ПАТ «Житомирський маслозавод» здійснюється за системою забезпечення конкурентоспроможності щодо підвищення конкурентних можливостей підприємства, зміцнення або утримання конкурентних позицій на ринку.

Висновки і пропозиції. В даний час існує безліч шляхів конкуренції та стратегій організації: виробнича, організаційна, товарна, цінова і т. ін. Проте слід зазначити, що в основі будь-якої стратегії лежать певні конкурентні переваги. Стратегічне управління можна розглядати у тому числі і як менеджмент конкурентними перевагами. Щоб бути конкурентоздатним підприємством на будь-якому ринку, компанія повинна мати унікальні конкурентні переваги та сформувати ефективну конкуренту стратегію. Найголовнішим ризиком зовнішнього середовища для підприємства є нестабільність політичної та економічної ситуації в країні та світі, адже компанія ПАТ «Житомирський маслозавод» являється виробником не лише життєво необхідної продукції. Підвищити конкурентоспроможність продукції ПАТ «Житомирський маслозавод» означає збільшити можливість утримання та підвищення конкурентної позиції підприємства за існуючих ринкових умов господарювання.

\section{СПИСОК ВИКОРИСТАНИХ ДЖЕРЕЛ}

1. Бурачек I.В., Біленчук О.О. Конкурентоспроможність продукції підприємств: сутність, методи оцінки та зарубіжний досвід управління. Глобальні та національні проблеми економіки. 2016. №14. С. 288-293

2. Должанський, I.3., Загорна Т.О. Конкурентоспроможність підприємства: навчальний посібник. К. : Центр навчальної літератури, 2010. 384 с.

3. Дуброва О.С. Процес розробки та реалізації конкурентної стратегії підприємства. $\begin{array}{lllll}\text { Ефективна } & \text { економіка. } & 2010 . & \text { № } & 8 .\end{array}$ http://www.economy.nayka.com.ua/index.php?Operation $=1$ \&iid= 332

4. Портер М. Конкурентная стратегия: методика анализа отраслей и конкурентов. М.: Альпина Бизнес Букс, 2013. - 454 с.

5. Сайт аналітичної компанії AR-group. URL:https://ar-group.kiev.ua

6. Офіційний сайт підприємства ПАТ «Житомирський маслозавод». URL: https://rud.ua/

\section{REFERENCES}

1. Burachek, I.V., Bilenchuk, O.O. Konkurentospromozhnist' produktsiyi pidpryyemstv: sutnist', metody otsinky ta zarubizhnyy dosvid upravlinnya. Hlobal'ni ta natsional'ni problemy ekonomiky. 2016. №14. S. 288-293

2. Dolzhans'kyy, I.Z., Zahorna T.O. Konkurentospromozhnist' pidpryyemstva: navchal'nyy posibnyk. K. : Tsentr navchal'noyi literatury, 2010. $384 \mathrm{~s}$.

3. Dubrova, O.S. Protses rozrobky ta realizatsiyi konkurentnoyi stratehiyi pidpryyemstva.

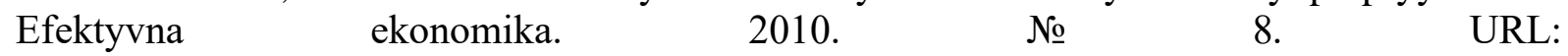
http://www.economy.nayka.com.ua/index.php?Operation $=1 \&$ iid $=332$

4. $\quad$ Porter, M. Konkurentnaya stratehyya: metodyka analyza otrasley y konkurentov. M.: Al'pyna Byznes Buks, 2013. - 454 s.

5. Sayt analitychnoyi kompaniyi AR-group. URL:https://ar-group.kiev.ua

6. Ofitsiynyy sayt pidpryyemstva PAT «Zhytomyrs'kyy maslozavod». URL: https://rud.ua/ 